\title{
Conceptualizing and Researching the Professionalization of Religious Education Teachers: Historical and International Perspectives
}

\author{
Rob Freathy ${ }^{\mathrm{a}}$, Stephen G. Parker ${ }^{\mathrm{b}}$, Friedrich Schweitzer ${ }^{\mathrm{c}}$ and Henrik Simojoki ${ }^{\mathrm{d}}$
}

a. Graduate School of Education, University of Exeter, Exeter, UK.

b. Institute of Education, University of Worcester, Worcester, UK.

c. Faculty of Protestant Theology, University of Tübingen, Tübingen, Germany.

d. Faculty of Human Sciences and Education, University of Bamberg, Bamberg, Germany.

\section{Notes on Contributors}

Rob Freathy is Associate Professor in History of Education in the Graduate School of Education at the University of Exeter, UK.

Stephen Parker is Professor of the History of Religion and Education in the Institute of Education at the University of Worcester, UK.

Friedrich Schweitzer is Professor of Practical Theology and Religious Education in the Faculty of Protestant Theology at the University of Tübingen, Germany.

Henrik Simojoki is Professor of Protestant Theology / Religious Education in the Faculty of Human Sciences at the University of Bamberg, Germany.

\begin{abstract}
Current discussions on Religious Education (RE), both in Germany and England, focus on the quality of teaching and the professionality of teachers, but neglect the historical and institutional process of professionalization upon which conceptions of teaching quality and teacher professionality hinge. This article seeks to provide definitional clarity by differentiating between individual and collective professionalization; exploring teacher professionalization in general and in the special case of RE; and operationalizing the concept of RE teacher professionalization for the purposes of planned historical and international comparative research. A three-fold conceptualization of professionalization is proposed, consisting of the following inter-related levels: (1) initial and continuing professional development; (2) professional self-organization and professional politics; and (3) professional knowledge. The breadth, complexity and significance of the historical and institutional processes associated with the professionalization of RE teachers at each of these levels is described and discussed. It is argued that further historical and international comparative research on these lines would contribute a broader and deeper understanding of the presuppositions of RE teacher professionality beyond current debates.
\end{abstract}

\section{Keywords}

Religious Education, Professionalization, Professionality, Professionalism

\section{Introduction}

This article calls for more attention to the professionalization of teachers in Religious Education (RE). Current discussions on RE, both in Germany and England, focus on the quality of teaching, and the characteristics and abilities of teachers. They tend to neglect the historical and institutional presuppositions upon which conceptions of teaching quality and the professional RE teacher hinge. This article seeks to provide conceptual clarity to these 
discussions, and delineate different dimensions of RE teacher professionalization. It calls for further research on the professionalization of RE teachers in historical and international comparative perspective. Research on professionalization in RE as proposed below would provide access to a broader and deeper understanding than evident in current debates.

In Germany, the growing interest in research on teachers of RE, and on their competencies, has found a visible expression in a rapidly growing literature on this topic (for an overview, see Burrichter et al. 2012; Heller \& Wermke 2013). In addition, there are monographs focussing on empirical approaches (e.g., Feige \& Tzscheetzsch 2005; Englert et al. 2006; Heil 2006; Lück 2012), special issues of the most important RE journals (e.g., ZPT 2/2014), and publications from the churches trying to provide orientation for the development of Higher Education (Kirchenamt der EKD 2008; Die deutschen Bischöfe 2010).

As can be seen from these publications, the new interest in the professionality of RE teachers is embedded in a whole series of developments, in society, politics and science. To mention the most important ones for Germany:

(1) the debates on the quality of school education triggered by the 'PISA shock' and its repercussions;

(2) the still unfinished process of restructuring teacher education within Higher Education based on the so-called Bologna process;

(3) the redirection and planning of processes of teaching on the basis of life-related competences and operationalizable standards; and finally,

(4) remarkable innovations in the field of empirical educational research opening up new possibilities for evaluating educational processes of professionalization.

In current English research on RE, most studies relating to the above topics have focused upon individual teachers' and trainee teachers' conceptions of professionality, with reference to their personal and professional life histories, gender and cultural identities, and faithperspectives (e.g., Bryan \& Revell 2011). Perhaps the most significant contribution in this area has been that of Judith Everington (e.g., Everington et al 2011, as well as her contribution to this issue). A smaller body of work has focused on the contribution of research in RE teacher professional development (Baumfield 2010; Stern 2014) and philosophical conceptions of 'a good RE teacher' (Orchard \& Whately 2013). Just as in Germany, recent debates on the professionality of teachers of RE can be interpreted as a reaction to contemporary challenges and impulses (APPG 2013). According to recent research findings, there is anxiety concerning the poor professional standing of RE teachers and teaching (Conroy et al. 2013), which is redolent of a long history characterised by a shortage of specialist teachers and advisors, and an insufficiency of initial and in-service teacher education (Copley 2008). In an attempt to increase the recruitment, improve the training, and recognise the success of RE teachers, some of the subject's stakeholders have engaged in a range of practical initiatives (Department for Education 2015; NATRE/REC 2013; Teach:RE 2015).

Why put something on the research agenda of RE, which is apparently already there? To understand our claim that the issue of professionalization needs to be addressed more thoroughly, some clarifications in terminology are needed (for more details cf. the article of Klaus-Peter Horn in this issue). Firstly, it is necessary to differentiate between the concepts of professionality and professionalization; secondly, one needs to distinguish between professionalization at an individual and professionalization at a collective level. 
- The concept of professionality refers to the characteristics and abilities that a professional teacher must acquire. With the policy-driven introduction of educational standards and competence-based curricula since the turn of the millennium, researching, defining and implementing professional standards for teachers has been at the centre of educational research and policy in Germany. Accordingly, as our brief literature overview indicates, the main emphasis of recent German studies on RE teachers clearly refers to their professionality. The influential recommendations for the training of RE teachers that were published by the Protestant Church of Germany in 2008 can be regarded as a prime example of this dominance. In the document, enhancing the 'competence in theology and religious education' serves as a comprehensive principal aim for teacher training in RE (Kirchenamt der EKD 2008).

- The professional characteristics, skills and competencies referred to above are acquired in individual learning processes which are shaped by teacher training as well as by biographical, contextual and personal factors. Following Ewald Terhart and others, these processes of professional development can be defined as 'individual professionalization' (Terhart 2005, 87f). As has been noted above, most recent studies on RE teachers in the UK focus on professionalization at the level of individual teachers, predominantly in relation to the personal, religious and identity perspectives of teachers joining the RE profession.

In the UK, much less attention has been paid to the fact that the individual process of acquiring professional competencies is actually embedded in much broader processes of professionalization at the collective level. Professionalization in this sense refers to the historical and institutional processes in which the teaching profession has assumed its specific professional shape. Due to the neglect of this background, which can only be understood historically, the contemporary debate on the professionalism and professionality of RE teacher lacks a solid basis.

In the following, this lacuna in RE is addressed by focusing specifically upon the historical and institutional processes that amount to the professionalization of teachers of RE at the collective level. The remainder of this article is divided into two main sections: The first part seeks to conceptualise what is meant by 'professionalisatization' in general and in relation to teachers of RE in particular. The second part presents ways of operationalizing this conception for research. Finally, some conclusions are drawn.

\section{Conceptualizing professionalization in Religious Education}

\subsection{Conceptualizing professionalization in educational research}

The concept of professionalization comes from the fields of history and sociology. It refers to certain types of worker who are set apart from others by particular characteristics, for example: professional training, a specialized body of knowledge, professional selforganization, and high standing in society. In historical and sociological studies by authors like Charles McClelland (1991), Rudolf Stichweh (1994) and Ulrich Oevermann (1996), the concept of professionalization was developed first in relationship to the so-called classic professions like medical doctors, and was then also applied, at least to some degree, to teachers.

Both in England and Germany, the study of professionalization is a well-established field of research in general education. In England, there have been a large number of studies examining, for example, the emergence of the professions in modernity (O'Day 2008), the intersections of professionalism with social class (Ozga \& Lawn 1981) and political economy (Neufeld 2009), teacher training and development (Crook 2011; Robinson 2011; 2014), the 
relationship between politics and professionalism (Lawn 1987; Robinson \& Bryce 2013), and the personal and professional identities of teachers (Cunningham \& Gardner 2004). Whilst earlier educational research was concerned to demonstrate the 'professional' qualities and credentials of all teachers, debates in more recent decades have been concerned with the extent to which the education professions are undermined and at risk, not least from politically-driven processes of de-professionalization (Sachs 2001).

In Germany, the professionalization of the teaching profession has also been thoroughly historically researched (overview: Kemnitz 2014), often using the concepts and categories of historical and sociological research. Such studies give central attention to core aspects of professionalization like the progressive academization of teacher training, or the emergence and the institutionalization of teacher associations. More recent studies try to be more independent of the classical concept of professionalization and instead attempt - in line with educational research (overview: Terhart et al. 2014) - to define the professional character of the teaching profession 'from the characteristics of this work itself' (Terhart 2011, 205).

\subsection{Religious Education - a Special Case?}

The research on teacher professionality and professionalization in general education provides important orientations for a deeper understanding of the professionalization of RE teachers. Yet the concepts and results discussed there cannot just be transferred to the teacher of RE, neither in terms of the theory of the professions, nor in terms of the history of professionalization.

With regard to Germany, this is due, in the first place, to the relationship of denominational $\mathrm{RE}$ to the church anchored in German Basic Law which does not only limit the possibilities for independent professional development of teachers in a specific manner, but also structurally shapes initial as well as continuing teacher development. Moreover, as described in more detail below, the professional knowledge of teachers of RE is characterized in a specific manner concerning the subject itself, as well as its content. Finally, professionality in RE finds expression in competent ways of coping with subject-specific antinomies and roleconflicts which result from the particular structural logic of the subject, its institutional ramifications and, ultimately, the indeterminacy of its core content (cf., for example, the 'tension between clearly advocating the Christian faith and the respect for other religious convictions and positions' which is basic for the competence model of the Gemischte Kommission der EKD [Kirchenamt der EKD 2008, 17]).

In spite of the research lacuna stated above there are some studies in RE that can be built upon. The practice of academic teacher training in Germany in the $19^{\text {th }}$ century has been described by David Käbisch and Johannes Wischmeyer, using the example of the minutes from classes at the Catechetical Seminary founded at the University of Jena in 1817 (Käbisch \& Wischmeyer 2008). Concerning the history of professionalization in RE during the Wilhelminian Era and the Weimar Republic, several studies are available (RoggenkampKaufmann 1999; Schweitzer \& Simojoki 2005). Yet for the time periods after that, there are basically no comparable historical studies. A number of smaller studies on the institutionalization of RE at German universities and other institutions of Higher Education are the only examples close to this research interest (cf. Schröder 2009). Concerning the need for understanding the contemporary debate on the professionality of the teacher of RE from a historical perspective, this gap in the existing research is especially disadvantageous since the academization of the training of teachers of RE beyond the Gymnasium teachers in Germany only gained momentum after 1945. It is ironic given that this is the epoch in which the 
present-day RE profession took shape that it is this period of history which remains underinvestigated.

In England, teacher professionalism, professional identity and professionalization are normally conceived in generic rather than subject-specific terms within academic, professional, political and public discourses. In the case of RE, this is curious and potentially unjustifiable given the exceptional legislative framework governing its unique position in the 'basic curriculum' of schools (Education Reform Act, 1988). In accordance with the 1944 Education Act, which established the core elements of the legal framework governing RE, the subject has to be provided by state-maintained schools to all pupils, except those withdrawn by their parents/guardians. In Local Education Authority (LEA) schools, it has to cohere with an Agreed Syllabus determined by a local conference (consisting of four committees representing the Church of England, other denominations, teachers and the local authority) advised by a local Standing Advisory Council for RE (SACRE). In academies, free schools and voluntary aided schools, RE is determined by the school's governing body.

Notwithstanding other curricular and pedagogical questions about the aims, methods and contents of the subject, including those about the ontological and epistemological assumptions underpinning its nature and purpose (Gearon 2014), these unusual arrangements for curriculum determination are sufficient to ensure that certain questions are raised about the professionalism, professional identity and professionalization of RE teachers that are quite unlike those asked of teachers other subjects.

\subsection{Professionalization of $R E$ teachers in international perspective}

In addition to the lack of historical studies, the international-comparative horizon is missing in the literature as well (Kemnitz 2014, 52, for exceptions see the empirical comparisons in Bakker \& Heimbrock 2007; Ziebertz \& Riegel 2009). This is despite the fact that research on teacher effectiveness and competencies is international, and potentially many lessons and insights could be learned from the study of professionalization and professional quality in other national contexts. International comparative research could provide better grounds for understanding the collective process of professionalization, especially if it included an historical dimension. Applying an analytical framework to the historical process of the professionalization of RE teachers with an international-comparative dimension would offer several advantages. It would enable national context-specific processes and factors to be identified. By looking at international and transnational discourses, developments and challenges, it would be easier to identify national particularities in policies, practices and processes, for example in terms of social, cultural or religious change, or with regard to the international harmonisation of educational structures and standards. Finally, the historicalcomparative dimension would make possible an assessment of developments in the respective national contexts, and the strengths and weaknesses of different models of professionalization.

In sum: during the last few years, the debate on the professionality of teachers of RE has markedly increased. In order to provide orientation towards a further professionalization of the RE teacher profession, this debate as well, as the related efforts to establish corresponding research, must be deepened in terms of its history and should also include international comparative perspectives.

\section{Researching professionalization in Religious Education}

Having identified the need for further research on the professionalization of teachers of RE, this section of the article presents one possible way of approaching such studies that the present authors are planning to pursue. It begins by articulating a three-fold conceptualization of professionalization before discussing how these concepts could be operationalized for the 
purposes of research. The definition below, following Freathy et al (2014), is based on conceptualisations found in the social sciences and in general education. It provides an analytical framework consisting of three inter-related conceptual levels (Table 1):

Table 1: Conceptual framework for the professionalization of RE

\begin{tabular}{|l|l|}
\hline Concept & Definition \\
\hline $\begin{array}{l}\text { Initial and continuing } \\
\text { professional development } \\
\text { (i.e. specialized and } \\
\text { advanced academic } \\
\text { education) }\end{array}$ & $\begin{array}{l}\text { The institutional structure, qualifications framework and official } \\
\text { curriculum of initial specialized and advanced training of teachers } \\
\text { of RE as undertaken by universities, HEIs and other providers } \\
\text { including those with(out) religious affiliations. }\end{array}$ \\
\hline $\begin{array}{l}\text { Professional self- } \\
\text { organization and } \\
\text { professional politics } \\
\text { (including legislation and } \\
\text { the role of faith } \\
\text { communities) }\end{array}$ & $\begin{array}{l}\text { The professional self-organization of teachers of RE including } \\
\text { professional associations (e.g., institutions, organizations, groups } \\
\text { and networks), legislation concerning RE teachers and teacher } \\
\text { training, and the professional politics of other collective actors like } \\
\text { faith communities. }\end{array}$ \\
\hline Professional knowledge & $\begin{array}{l}\text { The body of specialized knowledge associated with the } \\
\text { professionalization of teachers of RE. }\end{array}$ \\
\hline
\end{tabular}

Each of these concepts will now be described and discussed. For the purposes of exemplification, an explanation will be given as to how each level could be applied in historical and international comparative research on the professionalization of teachers of RE in England and Germany. Most of the examples will be drawn from the time period between 1945 and 1990 for which the authors are currently preparing a project proposal.

\subsection{Initial and continuing professional development}

Despite controversial discussions between different approaches to professionality and professionalization, there is broad agreement about the key role of specialized and advanced academic education for acquiring and maintaining professional expertise. Any understanding of teacher professionalization requires investigation of initial and continuing forms of teacher education. Relevant information can be gained by studying institutional structures (universities, teacher training colleges, institutions for continuing teacher training, etc.), the qualifications framework (examination regulations, certificates and awards, etc.), and the official curriculum and actual courses of initial specialised and advanced training of teachers of RE. Research in these areas is complex. Requirements and practices vary over time, and from institution to institution, many materials were never published or only in a limited form. The following issues, which refer to relational tensions in Higher Education-based teacher training, could be analysed. They include the relation between:

- $\quad$ the different courses of study and different levels of schooling, in terms of the length of programmes, admission requirements, academic levels and expected qualifications.

- different training components, in Theology, RE as subject-oriented didactics, general education and school-based practice-oriented internships.

- theory and praxis, and between academic work and professional demands.

- the orientations regarding schools and faith communities.

- initial and continuing teacher development.

- the traditionally male dominated profession and corresponding teaching situation at universities on the one hand, and the progressive feminization of the teaching profession on the other. 
In the German context, such explorations might consider, for example, the tensions between teacher training for the Gymnasium (schools for college-bound students) with its academic roots in the $19^{\text {th }}$ century on the one hand, and teacher training for other schools, such as Volks-, Grund- and Hauptschule which, until today, is less academized. This issue is associated with the relationship between universities and teacher colleges, and the academization of teacher training. Similarly, in England, it would be possible, for example, to explore the differences and/or relationships between (i) 4-year Bachelor in Education degrees and 1-year Postgraduate Certificate in Education programmes, (ii) postgraduate teacher training degrees and the undergraduate disciplines from which they recruit; (iii) types of teacher-training providers, including universities, teacher-training colleges and RE Teacher Centres; and (v) RE-specific training for specialist RE teachers (mostly secondary school teachers), and RE-specific training for generalist teachers or teachers of other subjects (mostly primary school teachers).

\subsection{Professional self-organization and professional politics}

On this second level, it is probably most obvious that there are limits to simply transferring social scientific conceptions of professionalism to the teacher of RE. With the classic professions (medical doctors, lawyers, etc.), professional autonomy is secured by the effective self-organization of the guild (in terms of qualifications, good practice, a professional ethos, etc.), and the representation of its interests. In the case of teachers, this characteristic has never been fully realized, thus teachers are often considered a semi-/quasi-profession. With teachers of RE, self-government and the leeway for independent self-interpretation is limited in two respects: on the one hand, because of their position in public service (in Germany, most often with the special status of Beamte), and on the other, because of the involvement of faith communities (and, in England, other stakeholders) in defining, governing and supporting RE. In Germany, for example, the churches control admissions to the profession via the churches' permit for teaching RE ('vocatio'). In England, for example, and as explained above, the churches perform a statutory role in determining RE Agreed Syllabuses for use in LEA schools and serving on local SACRE. Consequently, analysis of this aspect of the professionalization of teachers of RE in England and Germany would have to consider (i) the establishment of associations and the political representation of professional interests, and (ii) the formative influence of state regulation and the instruments of faith-related and other stakeholders for steering relevant processes in professional politics.

In England, such investigations could consider professional and subject associations, such as the Institute of Christian Education, the Student Christian Movement in Schools, the Christian Education Movement, the Association of Religious Education, the Religious Education Council for England and Wales, the Professional Council for RE, and the National Association of Teachers of RE. They should also consider government legislation for RE, and national political influence exercised by such bodies as the Central Advisory Council for Education (England), the School's Council, the Qualifications and Curriculum Authority, and Her Majesty's Inspectors/OFSTED. In terms of faith communities and their involvement in controlling and organising RE teachers and teaching, the specific expert committees and boards that have been founded over time could be investigated, including the Church of England's Board of Education and National Society for Promoting Religious Education, the Free Church Federal Council Education Committee, and the British Council of Churches' Education Department. In Germany, compared to the time of the German Empire and of the Weimar Republic, the influence of the Protestant associations of teachers of RE decreased after 1945, but the involvement of 'Arbeitsgemeinschaft Evangelischer Erzieher (in Deutschland)', albeit explicitly not as a status-related interest group, in professional politics 
could be explored. As in England, legal and school-related political rulings could be explored as they are foundational in providing a state-defined framework for professionalization, as well as the political activities of the Protestant Church in Germany (EKD) concerning professional politics in RE.

\subsection{Professional knowledge}

In the classical theories of professionalization, professional knowledge is a constitutive characteristic of professions. The professions differ from other kinds of occupations in being able to claim credibly that they have exclusive competence pertaining to a central societal problem. This competence is ascertained through the acquisition of highly-differentiated and university-based knowledge concerning their academic subject as well as their respective practice. The difficulty adapting the concept of the profession to teachers is that the stock of knowledge on which their expertise is based does not correspond to a single academic discipline or to a single, clearly-delineated domain of knowledge (cf. Lundgreen 2011). Originally, in questionable ways, this was seen as an indication of deficient professionalization. However, recent competence-orientated approaches, recognizing the complexity and multi-dimensionality of professional knowledge, can be applied to the professionality of teachers of RE. For this purpose, a modified version of the COACTIVmodel of teacher-professionality (Kunter et al 2011) could be used in the study of the professionalization of teachers of RE (see Table 2):

Table 2. Constituent elements of professional knowledge in RE

\begin{tabular}{|c|c|}
\hline Type of Knowledge & Definition \\
\hline Subject-specific content & $\begin{array}{c}\text { Subject-specific content knowledge, that is, knowledge and } \\
\text { skills appropriated from the academic study of religion(s) } \\
\text { and most frequently derived from Theology, Religious } \\
\text { Studies and cognate disciplines. }\end{array}$ \\
\hline $\begin{array}{c}\text { Subject-specific } \\
\text { pedagogical methods }\end{array}$ & $\begin{array}{c}\text { Knowledge of subject-specific pedagogical methods, } \\
\text { including the principles and procedures of teaching, } \\
\text { learning and assessing in RE. }\end{array}$ \\
\hline Orientative & $\begin{array}{c}\text { Orientative knowledge pertaining to the ontological and } \\
\text { epistemological foundations and the aims and purposes } \\
\text { (including those of a theological and/or religious nature) of } \\
\text { RE specifically, the wider curriculum and/or schooling in } \\
\text { general. }\end{array}$ \\
\hline $\begin{array}{c}\text { Generic pedagogical and } \\
\text { psychological }\end{array}$ & $\begin{array}{c}\text { Generic pedagogical and psychological knowledge drawn } \\
\text { from educational studies, educational psychology and } \\
\text { cognate disciplines which is widely applicable across } \\
\text { educational settings and curriculum-subjects including RE. }\end{array}$ \\
\hline $\begin{array}{c}\text { Knowledge of the professional identities, roles and } \\
\text { responsibilities of teachers, in RE specifically and in } \\
\text { and responsibilities } \\
\text { general, including a knowledge and understanding of the } \\
\text { skills and competencies required. }\end{array}$ \\
\hline
\end{tabular}

Central subject-related discourses and leading publications in RE could be systematically analysed in relation to these dimensions of knowledge. In historical perspective, the aim could be to capture continuities and changes in the content and structure of the professional knowledge of teachers of RE. Two genres of publications, which are central for the generation and appropriation of such knowledge, have been identified as candidates for further exploration. First, there are subject-related academic discourses in RE journals. In the history of RE in England these include Religion in Education (1934-1961), Learning for Living 
(1961-1978), and the British Journal of Religious Education (1978 onwards). Partial analyses of this journal(s) have been undertaken with regard to particular timeframes or content (Copley 1996; 1998; English et al 2003; 2005), but not so as to yield a systematic history of $\mathrm{RE}$ as a field of academic discourse nor specifically focusing on professionalization. Other journals could also be investigated, for example, the Bulletin of the Association of Lecturers and Teachers in Further and Higher Education (1965-1976), Journal of Beliefs and Values (1977 onwards), and Spectrum (1968-1996). In Germany, the leading publication has been the journal Der evangelische Erzieher: Zeitschrift für Pädagogik und Theologie (1949 onwards), which has already been analysed in relation to the concept of professionalization (cf. Schweitzer \& Simojoki 2005; Schweitzer et al. 2010). Second, there are core books on RE which can be defined as: (i) foundational theoretical contributions and (ii) textbooks and overviews that mean to present the core of the subject required for teacher-training programmes (cf. Simojoki 2014).

\section{Conclusions}

The above discussion shows that, firstly, it is possible to produce an operational definition of professionalization, and secondly, the breadth, complexity and significance of the historical and institutional processes associated with the professionalization of teachers of RE at each of the above conceptual levels is sufficient for them to warrant further scrutiny in future research. At least in our understanding, the threefold operationalization of the concept of professionalization with regard to the profession of RE teachers yields a meaningful way for doing this kind of research. Moreover, both the historical, as well as the international comparative perspective, are promising avenues for exploration, in that they are likely to give access to a broader understanding of the presuppositions of the professionality of RE teachers beyond current debates. It can arguably be expected that the results of such research could give these discussions a new and more solid basis by identifying the structural and institutional requirements of professionality that are often overlooked by approaches that neglect historical and/or international perspectives.

\section{Acknowledgements}

This work was supported by the Westhill Endowment Trust under Grant 1426/09/2014.

\section{References}

All Party Parliamentary Group. 2013. RE: The Truth Unmasked. The supply of and support for Religious Education teachers. An Inquiry by the All Party Parliamentary Group on Religious Education. http://www.recouncil.org.uk/images/stories/pdf/APPG_RE_The_Truth_Unmasked.pdf.

Bakker, C, and H.G. Heimbrock. ed. 2007. Researching RE Teachers: RE Teachers as Researchers. Münster: Waxmann.

Baumfield, V. 2010. "Towards a pedagogy for religious education: professional development through engagement in and with research.” British Journal of Religious Education 32(2): 89-91.

Bryan, H and L. Revell. 2011. "Performativity, faith and professional identity: Student religious education teachers and the ambiguities of objectivity." British Journal of Educational Studies 59(4): 403-419.

Burrichter, R., B. Grümme, H. Mendl, M.L. Pirner, M. Rothgangel, and T. Schlag. 2012. Professionell Religion unterrichten: Ein Arbeitsbuch. Stuttgart: Kohlhammer.

Conroy, J. C., D. Lundie, R. A. Davis, V. Baumfield, L. P. Barnes, Gallagher T., K. Lowden, N. Bourque, and K. Wenell. 2013. Does Religious Education Work? A multi-dimensional investigation. London: Bloomsbury.

Copley, T. 2008. Teaching Religion. Exeter: Exeter University Press. 
Copley, T. D. 1998. "Rediscovering the Past: Writings on Religious Education in Religion in Education Quarterly, 1934-39, Raise Some Questions for Today’s Religious Educators.” British Journal of Religious Education 20(2): 80-89.

Copley, T. 1996. "A Tribute to John Hull: A Review of Editorials in Learning for Living and the British Journal of Religious Education, 1971-1996.” British Journal of Religious Education 19(1): 5-12.

Crook, D. 2011. "In-service education and professional development for teachers in England: historical perspectives from the late twentieth century.” History of Education Researcher 87: 4-12.

Cunningham, P. and P. Gardner. 2004. Becoming Teachers: Texts and Testimonies 19071950. London: Woburn Press.

Department for Education. 2015. Get Into Teaching: Bursaries and Funding. http://www.education.gov.uk/get-into-teaching/funding/postgraduate-funding. [Accessed 15 May 2015].

Die deutschen Bischöfe. 2010. Kirchliche Anforderungen an die Religionslehrerbildung. Bonn: Sekretariat der Deutschen Bischofskonferenz.

Englert, R., B. Porzelt, A. Reese, and E. Stams. 2006. Innenansichten des Referendariats: Wie erleben angehende Religionslehrer/innen an Grundschulen ihren Vorbereitungsdienst? Eine empirische Untersuchung zur Entwicklung (religions)pädagogischer Handlungskompetenz. Berlin et al.: LIT.

English, L. M., M. O. D'Souza, and L. Chartrand. 2003. "A 10-year Retrospective of the British Journal of Religious Education: An Analysis of Contents and Contributors.” British Journal of Religious Education 25(4): 308-319.

English, L. M., M. O. D'Souza, and L. Chartrand. 2005. 'Comparative Analysis Of The Research and Publication Patterns In British Journal Of Religious Education And Religious Education.” Religious Education 100(2): 193-210.

Everington, J., Ina ter. Avest, C. Bakker, and A. van der Want. 2011. "European religious education teachers' perceptions of and responses to classroom diversity and their relationship to personal and professional biographies.” British Journal of Religious Education 33(2): 241-256.

Feige, A., and W. Tzscheetzsch. 2005. Christlicher Religionsunterricht im religionsneutralen Staat? Unterrichtliche Zielvorstellungen und religiöses Selbstverständnis von evangelischen und katholischen Religionslehrerinnen und -lehrern in Baden-Württemberg: Eine empirisch-repräsentative Befragung. Ostfildern: Schwaben-Verlag.

Freathy, R., S. Parker, F. Schweitzer, and H. Simojoki. 2014. "Towards International Comparative Research on the Professionalisation of Religious Education.” Journal of Beliefs and Values 35: 225-241.

Gearon, L. 2014. On Holy Ground: The Theory and Practice of Religious Education. Abingdon: Routledge.

Heil, S. 2006. Strukturprinzipien religionspädagogischer Professionalität: Wie Religionslehrerinnen und Religionslehrer auf die Bedeutung von Schülerzeichen schließen. Eine empirisch-fundierte Berufstheorie. Berlin: LIT.

Heller, T., and M. Wermke. ed 2013. Universitäre Religionslehrerbildung zwischen Berufsfeld- und Wissenschaftsbezug. Leipzig: EVA.

Käbisch, D., and J. Wischmeyer. 2008. Die Praxis akademischer Religionslehrerbildung: Katechetik und Pädagogik an der Universität Jena 1817 bis 1918. Tübingen: Mohr Siebeck.

Kemnitz, H. 2014. „Forschung zur Geschichte und Entwicklung des Lehrerberufs vom 18. Jahrhundert bis zur Gegenwart.“ In Handbuch der Forschung zum Lehrerberuf. 2. edition, edited by E. Terhart, H. Bennewitz, and M. Rothland, 52-72. Münster et al.: Waxmann. 
Kirchenamt der EKD. 2008. Theologisch-Religionspädagogische Kompetenz. Kompetenzen und Standards für die Religionslehrerbildung. Empfehlungen der Gemischten Kommission zur Reform des Theologiestudiums. Gütersloh: Gütersloher Verlagshaus.

Kunter, M., J. Baumert, W. Blum, U. Klussmann, S. Krauss, and M. Neubrand. 2011. Professionelle Kompetenz von Lehrkräften: Ergebnisse des Forschungsprogramms COACTIV. Münster et al.: Waxmann.

Lawn, M. 1987. Servants of the State: The Contested Control of Teaching 1900-1930. London: The Falmer Press.

Lück, C. 2012. Religion studieren: Eine bundesweite empirische Untersuchung zu der Studienzufriedenheit und den Studienmotiven und -belastungen angehender Religionslehrer/innen. Berlin u.a.: LIT.

Lundgreen, P. (2011). "Pädagogische Professionen. Ausbildung und Professionalität in historischer Perspektive.” In Pädagogische Professionalität, edited by W. Helsper, and R. Tippelt, 9-39. Weinheim et al.: Beltz.

McClelland, C.E. 1991. The German Experience of Professionalization. Modern Learned Professions and their Organizations from the Early Nineteenth Century to the Hitler Era. Cambridge/New York: Cambridge University Press.

National Association of Teachers of Religious Education and Religious Education Council for England and Wales. 2013. DFE Teacher standards 2013: An RE exemplification. http://www.natre.org.uk/uploads/Free\%20Resources/DFE\%20Teacher\%20standards\%202 013.pdf [Accessed 15 May 2015]

Neufeld, J. 2009. Redefining Teacher Development. London: Routledge.

O’Day, R. 2008. "Social change in the history of education: perspectives on the emergence of learned professions in England, c. 1500-1800”. In Social Change in the History of Britain, edited by Joyce Goodman, Gary McCulloch and William Richardson, 7-26. London: Routledge.

Oevermann, Ulrich. 1996. "Theoretische Skizze einer revidierten Theorie professionalisierten Handelns”. In Pädagogische Professionalität. Untersuchungen zum Typus pädagogischen Handelns, edited by A. Combe, and W. Helsper, 70-182. Frankfurt a.M.: Suhrkamp.

Orchard, J. and H. Whately. 2013. Practical wisdom and the good RE teacher: A case for change to Secondary ITT in RE in England. Oxford: Culham St Gabriel's.

Ozga, J. and M. Lawn. 1981. Teachers Professionalism and Class. London: The Falmer Press.

Robinson, W. 2011. “'That Great Educational Experiment' the City of London Vacation Course in Education 1922-1938: a forgotten story in the history of teacher professional development." History of Education 40(5): 557-575.

Robinson, W. 2014. A Learning Profession? Teachers and their Professional Development in England and Wales 1920-2000. Rotterdam: Sense Publishers.

Robinson, W. and Bryce, M. 2013. 'Capturing the 'Willing Enthusiasts' and 'Lame Ducks': Central government and the history of teacher professional development in England and Wales 1920-1975.” Paedagogica Historica 49(3): 345-360.

Roggenkamp-Kaufmann, A. 2001. Religionspädagogik als „Praktische Theologie“. Zur Entstehung der Religionspädagogik in Kaiserreich und Weimarer Republik. Leipzig: EVA.

Sachs, J. 2001. 'Teacher professional identity: competing discourses, competing outcomes.' Journal of Education Policy 16(2): 149-161.

Schröder, B. ed. 2009. Institutionalisierung und Profil der Religionspädagogik. Historischsystematische Studien zu ihrer Genese als Wissenschaft. Tübingen: Mohr-Siebeck.

Schweitzer, F., and H. Simojoki. 2005. Moderne Religionspädagogik. Ihre Entwicklung und Identität. Gütersloh, and Freiburg: Gütersloher Verlagshaus, and Herder. 
Schweitzer, F., H. Simojoki, S. Moschner, and M. Müller. 2010. Religionspädagogik als Wissenschaft. Transformationen der Disziplin im Spiegel ihrer Zeitschriften. Freiburg: Herder.

Simojoki, H. 2014. "Wie kann Religionspädagogik als Ganzes verstanden und dargestellt werden? Ein Literaturüberblick.” Verkündigung und Forschung 59 (2): 78-93.

Stern, J. 2014. 'The influence of research within religious education: the Westhill Seminars, RE professionals, pupils and schools.' British Journal of Religious Education 36(1): 18-38.

Stichweh, R. 1994. Wissenschaft, Universität, Profession: Soziologische Analysen. Frankfurt a.M.: Suhrkamp.

Teach: RE. 2015. RE Teaching: Beyond the Ordinary. http://www.teachre.co.uk/beyondtheordinary/ [Accessed 15 May 2015]

Terhart, E. 2005. "Pädagogische Qualität, Professionalisierung und Lehrerarbeit”. Vierteljahrsschrift für wissenschaftliche Pädagogik 81 (2): 79-97.

Terhart, E. 2011. "Lehrerberuf und Professionalität: Gewandeltes Begriffsverständnis - neue Herausforderungen.” In Pädagogische Professionalität, edited by W. Helsper, and R. Tippelt, 202-224. Weinheim et al.: Beltz.

Terhart, E., H. Bennewitz, and M. Rothland. ed. 2014. Handbuch der Forschung zum Lehrerberuf. 2. edition. Münster et al. Waxmann.

Ziebertz, H.-G., and U. Riegel. ed. 2009. How Teachers in Europe Teach Religion: An International Empirical Study in 16 Countries. Münster: LIT. 